\title{
Desferrioxamine attenuates minor lung injury following surgical acute liver failure
}

\author{
G.G. Kostopanagiotou*, K.A. Kalimeris*, N.P. Arkadopoulos*, A. Pafiti ", \\ D. Panagopoulos ${ }^{\#}$, V. Smyrniotis $\#$, D. Vlahakos ${ }^{+}$, C. Routsi ${ }^{\S, \# \#, ~}$ \\ M.E. Lekka ${ }^{f}$ and G. Nakos**,\#\#
}

ABSTRACT: Acute liver failure (ALF) can be complicated by lung dysfunction. The aim of this study was to test the hypothesis that inhibition of oxidative stress through iron chelation with desferrioxamine (DFX) attenuates pulmonary injury caused by ALF.

14 adult female domestic pigs were subjected to surgical devascularisation of the liver and were randomised to a study group (DFX group, $n=7$ ), which received post-operative intravenous infusion of DFX $\left(14.5 \mathrm{mg} \cdot \mathrm{kg}^{-1} \cdot \mathrm{h}^{-1}\right.$ for the first $6 \mathrm{~h}$ post-operatively and $2.4 \mathrm{mg} \cdot \mathrm{kg}^{-1} \cdot \mathrm{h}^{-1}$ until completion of $24 \mathrm{~h})$, and a control group $(n=7)$. Post-operative lung damage was evaluated by histological and bronchoalveolar lavage fluid (BALF) analysis.

DFX resulted in reduced BALF protein levels and tissue phospholipase (PL) $A_{2}$ activity. Plasma malondialdehyde and BALF nitrate and nitrite concentrations were lower, while catalase activity in the lung was higher after DFX treatment. PLA cell counts in BALF did not differ between groups. Histological examination revealed reduced alveolar collapse, pneumonocyte necrosis and total lung injury in the DFX-treated animals.

DFX reduced systemic and pulmonary oxidative stress during ALF. The limited activity of PLA and the attenuation of pneumonocyte necrosis could represent beneficial mechanisms by which DFX improves alveolar-capillary membrane permeability and prevents alveolar space collapse.

KEYWORDS: Alveolocapillary permeability, antioxidants, iron regulation, liver-lung interactions, lung injury, oxidants

\begin{abstract}
A cute liver failure (ALF) induces systemic derangements, including pulmonary oedema $[1,2]$. We previously showed that surgical devascularisation of the liver produces inflammatory alterations in bronchoalveolar lavage fluid (BALF) and lung histology [3]. Numerous studies suggest that inflammation during lung injury necessitates that oxidative molecule production overwhelms the antioxidant defences of the lung $[4,5]$. Since ALF and portocaval shunting induce oxidative stress in not only the liver but also systemic circulation and remote organs, we hypothesised that during ALF the lung could be exposed to increased oxidative stress [6-8].
\end{abstract}

Oxidative reactions are mediated by iron, which catalyses hydroxyl radical production. Studies have shown that desferrioxamine (DFX), a potent iron chelator, improves experimental liver failure and liver transplantation by attenuating oxidative stress $[9,10]$. Interestingly, the antioxidant effects of iron chelation were also proven beneficial in models of lung injury [11, 12].

Apart from liver transplantation, no therapeutic interventions are available today for lung injury during ALF [13]. The hypothesis behind our study was that oxidative stress could mediate remote lung injury during devascularisation of the liver. In this respect, we aimed to investigate whether iron chelation with DFX could alleviate oxidative stress and improve lung damage in pigs with surgically induced, severe ALF.

\section{MATERIALS AND METHODS}

The protocol was approved by the Animal Research Committee of the University of Athens (Athens, Greece). Care and handling of the animals was in accordance with National and European guidelines for ethical animal research.

\section{Induction and maintenance of anaesthesia}

14 young adult female domestic pigs (22-25 kg, 3-4 months old) were used. After 24-h deprivation of food and unrestricted access to water, $4 \mathrm{mg} \cdot \mathrm{kg}^{-1}$ ketamine, $0.2 \mathrm{mg} \cdot \mathrm{kg}^{-1}$ midazolam and $0.5 \mathrm{mg}$ atropine were administered intramuscularly. General anaesthesia was induced with $5 \mathrm{mg} \cdot \mathrm{kg}^{-1}$ thiopental sodium and $2 \mathrm{mg} \cdot \mathrm{kg}^{-1} \mathrm{keta}-$ mine via an ear peripheral vein. The trachea was intubated with a cuffed tube of internal diameter

\section{AFFILIATIONS}

*Second Dept of Anaesthesiology and

+Second Dept of Internal Medicine, University of Athens School of Medicine, Attikon Hospital, Athens \#Second Dept of Surgery and "Dept of Pathology, University of Athens School of Medicine, Aretaieion Hospital, Athens ${ }^{\S}$ First Dept of Critical Care, University of Athens School of Medicine, Evangelismos Hospital, Athens ${ }^{f}$ Dept of Biochemistry ${ }^{*}$ Dept of Critical Care, University of Ioannina, University Hospital, Ioannina, Greece

\#\#Both authors equally undertook a critical revision of intellectual content and gave final manuscript approval.

CORRESPONDENCE

G. Nakos,

Intensive Care Unit,

School of Medicine

University of loannina Hospital, loannina, 45500,

Greece

E-mail: gnakos@cc.uoi.gr

\section{Received:}

August 092008

Accepted after revision:

November 112008

\section{SUPPORT STATEMENT}

This project was co-funded by the European Social Fund and National Resources: PYTHAGORAS ॥.

STATEMENT OF INTEREST

None declared

European Respiratory Journal Print ISSN 0903-1936 Online ISSN 1399-3003 
of 5.5-6.0 $\mathrm{mm}$ and mechanical ventilation was initiated using a volume ventilator (Sulla 808 V; Dräger, Lübeck, Germany), with an inspiratory oxygen fraction $\left(\mathrm{FI}, \mathrm{O}_{2}\right)$ of 0.6 , a tidal volume of $10 \mathrm{~mL} \cdot \mathrm{kg}^{-1}$, no positive end-expiratory pressure and a respiratory frequency of $10-15$ breaths $\cdot \mathrm{min}^{-1}$, so that end-tidal $\mathrm{CO}_{2}$ tension $\left(\mathrm{PET}, \mathrm{CO}_{2}\right)$ was $35-45 \mathrm{mmHg}$.

Following insertion of an orogastric tube, $10-20 \mu \mathrm{g} \cdot \mathrm{kg}^{-1}$ fentanyl and $0.5 \mathrm{mg} \cdot \mathrm{kg}^{-1}$ vecuronium bromide were given intravenously. Then the right external jugular vein was exposed and a central vein catheter 6.5Fr (G986; Arrow International, Reading, PA, USA) was inserted in order to obtain central venous pressure measurements and blood samples. The right carotid artery was cannulated with a $20 \mathrm{G}$ catheter for arterial pressure monitoring. Blood samples were obtained at 0,7 and $24 \mathrm{~h}$ post-operatively. $750 \mathrm{mg}$ of i.v. cefuroxime was given every $6 \mathrm{~h}$, beginning from incision. Anaesthesia was maintained with continuous i.v. infusion of 15-20 $\mathrm{gg} \cdot \mathrm{kg}^{-1} \cdot \mathrm{h}^{-1}$ fentanyl, $5-8 \mathrm{mg} \cdot \mathrm{kg}^{-1} \cdot \mathrm{h}^{-1}$ ketamine and $0.5 \mathrm{mg} \cdot \mathrm{kg}^{-1} \cdot \mathrm{h}^{-1}$ vecuronium bromide. Solutions of $5 \%$ dextrose, normal saline, $6 \%$ hydroxyethylstarch and lactated Ringer's, 100-200 $\mathrm{mL} \cdot \mathrm{h}^{-1}$ each, were given in order to maintain normoglycaemia, normal electrolytic values and central venous pressure of $4-9 \mathrm{mmHg}$.

\section{Surgical procedure}

Briefly, a midline abdominal incision was followed by an endto-side portocaval anastomosis and transection of the hepatoduodenal ligament with its contents (hepatic artery and bile duct). In order to ensure interruption of collateral blood flow, all other ligamentous attachments of the liver were also transected. The procedure lasted $\sim 60 \mathrm{~min}$. At the end of the experiment, animals were euthanised with $2 \mathrm{~g} \mathrm{KCl}, 20 \mathrm{~mL}$ of $1 \%$ propofol and $20 \mathrm{mg}$ vecuronium bromide. Autopsies verified absence of surgical complications and confirmed total liver necrosis in all animals. Biopsies were taken from the liver as well as the lower lobe of the left lung and were used for histological examination and tissue analysis.

\section{DFX protocol}

In seven randomly chosen animals DFX was given as follows: $2 \mathrm{~g}$ DFX in $250 \mathrm{~mL}$ of $5 \%$ dextrose were given during the first $6 \mathrm{~h}\left(14.5 \mathrm{mg} \cdot \mathrm{kg}^{-1} \cdot \mathrm{h}^{-1}\right)$, whereas for the next $18 \mathrm{~h}$ animals received $1 \mathrm{~g}$ DFX in $250 \mathrm{~mL}$ of $5 \%$ dextrose $\left(2.4 \mathrm{mg} \cdot \mathrm{kg}^{-1} \cdot \mathrm{h}^{-1}\right)$.

\section{Bronchoalveolar lavage procedure}

Bronchoalveolar lavage was performed with a fibreoptic bronchoscope (Fujinon BDR-YP 2; Fuji, Saitama, Japan) after the insertion of central lines (baseline), immediately after completion of surgery $(0 \mathrm{~h})$, and at 7 and $24 \mathrm{~h}$ post-operatively. The bronchoscope was introduced through a swivel adaptor in the right middle lobe (recovery 50-75\%). The first aspirated fluid reflecting a bronchial sample was discarded. BALF was then filtered through sterile gauze, collected and immediately centrifuged at $500 \times g$ for $10 \mathrm{~min}$ at $4^{\circ} \mathrm{C}$. The supernatant was stored at $-80^{\circ} \mathrm{C}$ for biochemical analyses.

\section{Tissue homogenisation}

Lung tissue samples were weighed and homogenised in cold phosphate buffer saline, $\mathrm{pH} 7.4$, to produce a 1/10 (weight/ volume) homogenate. A teflon pestle was used for tissue homogenisation. The homogenate was sonicated and centrifuged at $800 \times g$ for $15 \mathrm{~min}$. The supernatant was aliquoted and kept at $-20^{\circ} \mathrm{C}$ until use.

\section{Total protein, iron and cells in BALF}

Total protein in BALF and tissue homogenates was measured according to LOWRY et al. [14]. Serum total iron was measured using a commercially available set (BioAssay Systems, Hayward, CA, USA). Total BALF cells and differential counts were performed by counting at least 300 cells in cytocentrifuge preparations stained with haematoxylin-eosin.

\section{Phospholipase $A_{2}$ and platelet-activating factor acetylhydrolase assays}

Phospholipase (PL)A $\mathrm{A}_{2}$ was measured fluorometrically with $\mathrm{C}_{12}$-NBD-PC as substrate using either BALF or supernatant of the homogenate [15]. BALF platelet activating factor acetylhydrolase (PAF-AcH) was determined after incubating BALF with $\left[{ }^{3} \mathrm{H}\right]$-platelet-activating factor (PAF) and measuring the radioactivity of the acetyl group, as previously described $[15,16]$.

\section{Nitrite/nitrate measurement}

Nitrites and nitrates were quantified colorimetrically after their reaction with Griess reagent. A nitrate standard solution $(100 \mu \mathrm{L})$ was serially diluted (generally from $80-5 \mu \mathrm{M})$ in duplicate in a 96-well microtitre plate. Reduction of nitrate to nitrite with $\mathrm{VCl}_{3}(100 \mu \mathrm{L})$ was rapidly followed by addition of Griess reagent, $50 \mu \mathrm{L}$ sulfanilamide and $50 \mu \mathrm{L} \mathrm{N}$-(1-naphthy1)ethylenediamine dihydrochloride. Nitrite was measured similarly except that samples and nitrite standards were exposed only to Griess reagent. In either case, absorbance was measured at $540 \mathrm{~nm}$.

\section{Malondialdehyde and catalase measurement}

Briefly, $0.65 \mathrm{~mL}$ of $10.3 \mathrm{mM} N$-methyl-2-phenyl-indole in acetonitrile was added to $0.2 \mathrm{~mL}$ of plasma. After vortexing for $3-4 \mathrm{~s}$ and adding $0.15 \mathrm{~mL}$ of $37 \% \mathrm{HCl}$, samples were incubated at $45^{\circ} \mathrm{C}$ for $60 \mathrm{~min}$. The samples were ice cooled and centrifuged and the absorbance was measured spectrophotometrically at $586 \mathrm{~nm}$. A calibration curve of an accurately prepared standard malondialdehyde (MDA) solution (2$20 \mathrm{nmol} \cdot \mathrm{mL}^{-1}$ ) was run for quantitation. All measurements were performed in triplicate. Catalase activity was measured spectrophotometrically using a kit from Oxis Health Products Inc. (Portland, OR, USA).

\section{Histological examination}

Lung biopsies fixed with buffered formalin, cut into $3-5-\mu \mathrm{m}$ sections and stained with haematoxylin-eosin, were blindly evaluated by two pathologists, using a previously described scoring system for acute lung injury [17]. Appropriate modifications to this system were deemed essential in order to include all main histological findings, since no scoring system exists for this particular model of lung damage. Each section was given a score of 0 to 4 for alveolar collapse, haemorrhage, alveolar and interstitial oedema, necrosis of alveolar epithelial cells (AECs), and infiltration of lymphocytes and leukocytes. For example, for alveolar collapse: 0: no alveolar collapse; 1: occasional fields with a low number of collapsed alveoli per field (minimal); 2: occasional fields with increased number (more than three) of collapsed alveoli per 
viewed field (mild); 3: many, but not all, fields with alveolar collapse; and 4: alveolar collapse in all fields examined (severe). Total lung injury score of each section was calculated by adding the separate scores. Paraffin-fixed sections of liver biopsies were stained with haematoxylin-eosin and evaluated by the same pathologists.

\section{Statistics}

Data are expressed as mean \pm SD. Differences between different time-points within each group were analysed with one-way repeated measures ANOVA followed by the Bonferroni post hoc test for multiple comparisons. Differences between the two groups were analysed with ANCOVA, where baseline values, or values at $0 \mathrm{~h}$ if baseline values were missing, were set as covariance. Parameters measured only once were compared with simple ANOVA. Statistical analysis was processed with SPSS v.15.0 software and was approved by a specialist in statistics. A p-value $<0.05$ was considered significant.

\section{RESULTS}

\section{Haemodynamics, blood gases and serum markers}

Mean arterial pressure decreased in controls at $24 \mathrm{~h}$, being lower compared with the DFX group. No statistical differences were found between or inside groups regarding cardiac frequency, the arterial oxygen tension $\left(\mathrm{Pa}_{2} \mathrm{O}_{2}\right) / \mathrm{FI}_{1} \mathrm{O}_{2}$ ratio, arterial carbon dioxide tension $\left(\mathrm{Pa}_{\mathrm{a}} \mathrm{CO}_{2}\right), \mathrm{pH}$ or temperature (table 1). Hyperbilirubinaemia developed gradually in both groups. Serum iron levels decreased in the DFX group and were lower than in controls at 7 and $24 \mathrm{~h}$. Plasma MDA levels increased at 7 and $24 \mathrm{~h}$ in controls, whereas in the DFX group, MDA increased at only $7 \mathrm{~h}$. At $24 \mathrm{~h}$ plasma MDA levels were lower in the DFX group compared with controls (table 2).

\section{BALF protein}

Total protein in BALF increased in both groups compared with baseline values. In the DFX group, BALF total protein was statistically lower than in controls both at 7 and at $24 \mathrm{~h}$ (fig. 1). In addition, the BALF to serum protein ratio was also statistically lower in the DFX group at 7 and $24 \mathrm{~h}$ (table 3 ).

\section{$\mathrm{PLA}_{2}$ and PAF-ACH}

In controls, BALF PLA 2 levels increased at $0 \mathrm{~h}$ and subsequently decreased. In the DFX group no significant changes from baseline values were observed. The ratio of $\mathrm{PLA}_{2}$ activity to total protein in BALF did not change in either group but was higher in the DFX group compared with controls at $24 \mathrm{~h}$ (table 3). However, when PLA 2 activity was measured in lung tissue, it was significantly lower in the DFX group $\left(0.397 \pm 0.251 \mathrm{nmol} \mathrm{FA} \cdot \mathrm{h}^{-1} \cdot \mathrm{mg}^{-1}\right.$ protein $)$ compared with controls $\left(0.824 \pm 0.331 \mathrm{nmol} \mathrm{FA} \cdot \mathrm{h}^{-1} \cdot \mathrm{mg}^{-1}\right.$ protein $)(\mathrm{p}=0.026)$.

BALF PAF-AcH levels in controls increased immediately after devascularisation and then decreased. A similar pattern was observed in the DFX group, but no significant changes were found over time. The two groups did not differ in PAF-AcH levels or in the ratio of PAF-AcH to BALF protein (table 3).

\section{BALF NO products $\left(\mathrm{NO}_{2}^{-}\right.$and $\left.\mathrm{NO}_{3}{ }^{-}\right)$and tissue catalase activity}

BALF nitrite and nitrate levels increased significantly $7 \mathrm{~h}$ postoperatively in controls and then decreased towards initial values. In contrast, no change from initial levels was observed

\begin{tabular}{lcccc}
\hline TABLE $\mathbf{1}$ & \multicolumn{3}{c}{ Haemodynamic parameters and blood gases in } \\
control and desferrioxamine (DFX) groups
\end{tabular}

Data are presented as mean $\pm \mathrm{SD}$. Ventilation settings were: tidal volume $10 \mathrm{~mL} \cdot \mathrm{kg}^{-1}$, no positive end-expiratory pressure, inspiratory oxygen fraction $\left(\mathrm{Fl}_{1} \mathrm{O}_{2}\right)$ of 0.60 , respiratory rate adjustment of $10-15$ breaths $\cdot \mathrm{min}^{-1}$ to maintain end-tidal $\mathrm{CO}_{2}$ tension between $35-45 \mathrm{mmHg}$. $\bar{P}$ a: mean arterial pressure; $\mathrm{fC}$ : cardiac frequency; $\mathrm{Pa}_{2} \mathrm{O}_{2}$ : arterial oxygen tension; $\overline{\mathrm{Pa}}_{\mathrm{a}} \mathrm{CO}_{2}$ : arterial carbon dioxide tension. ${ }^{*}$ : normal temperature for pigs is $38.5 \pm 1^{\circ} \mathrm{C}$; $*$ : $p<0.05$ compared with baseline values in the same group; ${ }^{* *}: p<0.01$ compared with control group.

in the DFX group (table 3 and fig. 2). Levels of nitrites and nitrates were significantly higher in controls at $7 \mathrm{~h}$ compared with the DFX group.

Catalase activity in lung tissue at $24 \mathrm{~h}$ was significantly higher in the DFX group $\left(38.07 \pm 22.88 \mathrm{U} \cdot \mathrm{mL}^{-1}\right)$ compared with controls $\left(11.23 \pm 6.01 \mathrm{U} \cdot \mathrm{mL}^{-1}\right)(\mathrm{p}=0.021)$.

\section{BALF cells}

In controls, a significant increase was noted in BALF total cells and neutrophil counts at $7 \mathrm{~h}$. This was accompanied by decreased percentages of alveolar macrophages and increased percentages of neutrophils both at 7 and $24 \mathrm{~h}$. In contrast, no statistically significant changes were noted in total cell counts or percentages of alveolar macrophages or neutrophils in the DFX group. However, increased alveolar macrophage counts were noted both at 0 and $7 \mathrm{~h}$ compared with baseline values. The two groups did not differ between them at any time point (table 4).

\section{Histopathology}

Histopathological scoring in the two groups is presented in table 5. In the DFX group, alveolar collapse and necrotised AECs inside the alveoli were fewer compared with controls (fig. 3). Total lung injury score was also significantly less in the DFX group. Liver biopsies confirmed the presence of extensive centrolobular necrosis in all animals. 


\begin{tabular}{|c|c|c|c|c|c|}
\hline TABLE 2 & $\begin{array}{l}\text { Ser } \\
\text { mal } \\
\text { con } \\
\text { (DF }\end{array}$ & $\begin{array}{l}\text { n total pr } \\
\text { ndialdehy } \\
\text { entrations } \\
\text { groups }\end{array}$ & $\begin{array}{l}\text { tein, serur } \\
\text { de (MDA) } \\
\text { in control }\end{array}$ & $\begin{array}{l}\text { n iron, plas } \\
\text { and serum } \\
\text { and desfer }\end{array}$ & $\begin{array}{l}\text { sma } \\
\text { bilirubin } \\
\text { rioxamine }\end{array}$ \\
\hline Parameter & & Baseline & $\mathrm{Oh}$ & $7 \mathrm{~h}$ & $24 \mathrm{~h}$ \\
\hline \multicolumn{5}{|c|}{ Total serum protein } & \\
\hline Control grour & & & $4.9 \pm 0.7$ & $4.1 \pm 0.4^{\circ}$ & $2.2 \pm 0.5^{\bullet ⿻,+}$ \\
\hline DFX group & & & $5.7 \pm 0.8$ & $4.9 \pm 0.8^{\circ}$ & $3.5 \pm 0.4 \%,+, * *$ \\
\hline \multicolumn{6}{|c|}{$\begin{array}{l}\text { Serum iron levels } \\
\mu \mathrm{g} \cdot \mathrm{dL}^{-1}\end{array}$} \\
\hline Control grour & & & $95 \pm 34$ & $69 \pm 26$ & $108 \pm 50$ \\
\hline DFX group & & & $105 \pm 63$ & $18 \pm 28^{*} * * *$ & $43 \pm 51^{*}$ \\
\hline \multicolumn{6}{|l|}{$\begin{array}{c}\text { Plasma MDA } \\
\mathrm{nmol} \cdot \mathrm{mL}^{-1}\end{array}$} \\
\hline Control grour & & $1.7 \pm 0.6$ & & $3.3 \pm 0.3^{\#}$ & $5.7 \pm 1.8^{\#}$ \\
\hline DFX group & & $1.4 \pm 0.5$ & & $3.3 \pm 0.3^{\# \#}$ & $3.5 \pm 1.5^{\star}$ \\
\hline \multicolumn{6}{|c|}{$\begin{array}{l}\text { Total serum } \\
\text { bilirubin } \mathrm{mg} \cdot \mathrm{dL}^{-1}\end{array}$} \\
\hline Control group & & & $0.08 \pm 0.08$ & $0.89 \pm 0.62^{\circ}$ & $1.31 \pm 0.87^{\circ}$ \\
\hline DFX group & & & $0.10 \pm 0.11$ & $0.74 \pm 0.51^{\circ}$ & $1.31 \pm 0.91^{\circ}$ \\
\hline
\end{tabular}

Data are presented as mean \pm SD. ${ }^{*}: \mathrm{p}<0.05$ and ${ }^{* *}: \mathrm{p}<0.01$ compared with control group; $\#: p<0.05$ and ${ }^{\# \#: ~} p<0.01$ compared with baseline values; $\because p<0.05$ and $": p<0.01$ compared with $0 \mathrm{~h}$ (immediately after completion of surgery); ${ }^{+}: p<0.05$ and ${ }^{++}: p<0.01$ compared with $7 \mathrm{~h}$ ( $7 \mathrm{~h}$ after completion of surgery) in the same group

\section{DISCUSSION}

The applied surgical model of ALF induction resulted in rapid loss of detoxifying liver function and complete, histologically confirmed liver necrosis by the end of the experiment. The infusion of DFX resulted in a clear reduction of oxidative stress in plasma and BALF and enhanced catalase activity. BALF protein concentration, $\mathrm{BALF} /$ serum ratio and tissue $\mathrm{PLA}_{2}$ activity also decreased significantly. These results were accompanied by less AEC necrosis, alveolar collapse and total histological lung injury. The present data provide the first experimental demonstration that lung injury due to ALF is, at least partially, mediated by oxidative molecules, and that inhibition of iron-dependent oxidative reactions alleviates lung injury during ongoing ALF.

Iron-catalysed oxidative stress and disruption of iron homeostasis have been involved in many pulmonary diseases, including acute respiratory distress syndrome (ARDS) [11, 18]. Iron may contribute to alveolar-capillary membrane injury and lung inflammation in ARDS by yielding hydroxyl radicals through the Fenton-Haber-Weiss reaction [4, 11]. Iron chelation by DFX inhibits this reaction, thereby reducing the production of hydroxyl radicals. Additionally, DFX directly scavenges peroxyl radicals and inhibits nitrosative stress [10]. These antioxidative actions of DFX significantly improved lung function during lipopolysaccharide-induced lung injury [12].

In our experiment, DFX provided antioxidative protection both systematically and locally in the lung, as shown by the decreased plasma MDA and BALF NO levels and the

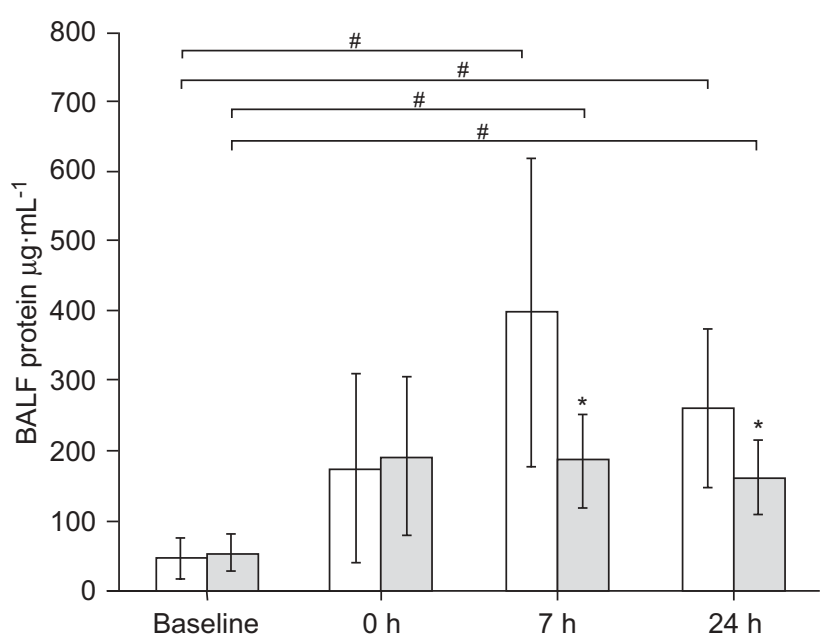

FIGURE 1. Time course of total protein levels in bronchoalveolar lavage fluid (BALF) from pigs subjected to liver devascularisation (0 h). The control group ( $\square$ ) did not receive antioxidant therapy, while pigs in the desferrioxamine group ( $\square$ ) received postoperative i.v. infusion of desferrioxamine for $24 \mathrm{~h} .{ }^{*}: \mathrm{p}<0.05$ between the two groups at 7 and $24 \mathrm{~h} ;{ }^{*}: \mathrm{p}<0.05$ between the depicted time-points within each group.

increased catalase activity. Lipid peroxidation in the lung probably could contribute to plasma MDA, since plasma MDA levels were shown to depend on the degree of lung injury [19]. Nitric oxide is a well-known oxidative molecule which oxidises protein residues to nitrotyrosine, altering cellular signalling processes and inducing apoptosis [20]. In contrast, catalase converts hydrogen peroxide $\left(\mathrm{H}_{2} \mathrm{O}_{2}\right)$ to molecular $\mathrm{O}_{2}$ and $\mathrm{H}_{2} \mathrm{O}$, thereby augmenting antioxidant capacity [21]. Therefore, the reduction of oxidative products along with enhancement of antioxidant defences could account for there being less damage to the alveolar-capillary membrane proteins and cells. Additionally, inhibition of NO production may have also contributed to the observed haemodynamic stability by preventing ALF-induced vasodilatation [22].

The increase in BALF protein could result from either increased alveolar fluid volume recovery or increased alveolar protein concentration. Although alveolar fluid increase could result from increased lavaged area, this distinction is not possible due to the absence of reliable alveolar fluid volume markers [16]; however, the reproducibility of the results suggests that the increased protein occurs mainly due to increased alveolar protein concentration. The latter could ensue from disturbance and increased permeability of the alveolar-capillary membrane [23]. Therefore, the reduction of BALF protein suggests that DFX partially attenuated the alveolar-capillary barrier disruption. Antioxidant protection and preservation of the AECs could have contributed to this, by preserving the alveolar-capillary membrane integrity and preventing protein influx into the alveoli.

$\mathrm{PLA}_{2}$ hydrolyses surfactant phospholipids and induces the production of PAF, thus contributing to local inflammation [24]. Increased $\mathrm{PLA}_{2}$ levels are assumed to derive either locally from inflammatory cells or from the circulation [25]. Although $\mathrm{PLA}_{2}$ and PAF-AcH levels did not clearly differ between the two groups in BALF, tissue PLA 2 activity decreased in the DFX 
TABLE 3 Biochemical parameters in bronchoalveolar lavage fluid (BALF) in control and desferrioxamine (DFX) groups

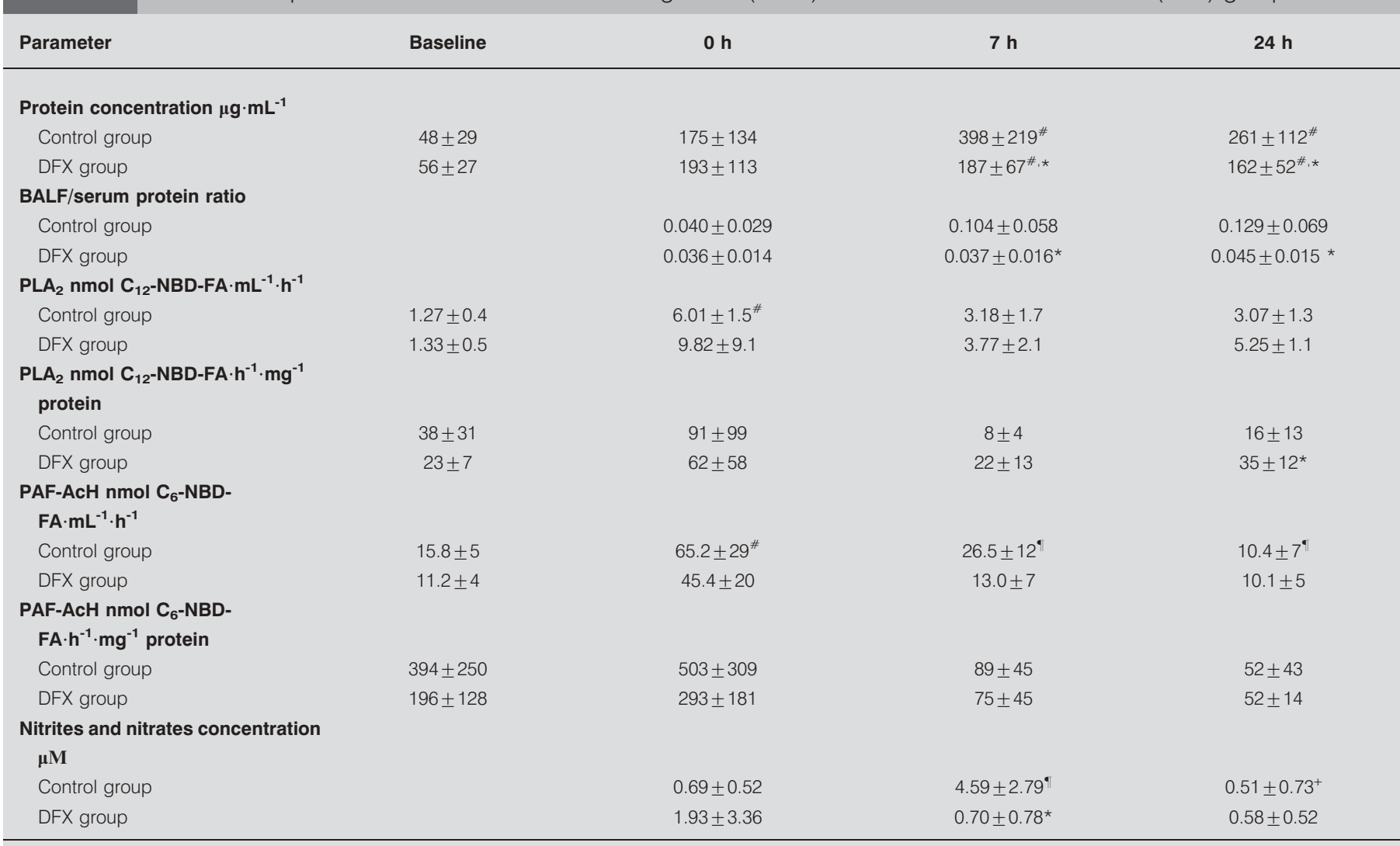

Data are presented as mean $\pm \mathrm{SD}$. Ventilation settings were: tidal volume $10 \mathrm{~mL} \cdot \mathrm{kg}^{-1}$, no positive end-expiratory pressure, inspiratory oxygen fraction of 0.60 , respiratory rate adjustment of $10-15$ breaths $\cdot \mathrm{min}^{-1}$ to maintain end-tidal $\mathrm{CO}_{2}$ tension of $35-45 \mathrm{mmHg}$. PL: phospholipase; PAF-AcH: platelet-activating factor acetylhydrolase. *: $\mathrm{p}<0.05$ compared with control group; ${ }^{*}: \mathrm{p}<0.05$ compared with baseline values; ${ }^{\top}: \mathrm{p}<0.05$ compared with $0 \mathrm{~h}$ (immediately after completion of surgery); ${ }^{+}: \mathrm{p}<0.05$ compared with $7 \mathrm{~h}$ ( $7 \mathrm{~h}$ after completion of surgery) in the same group.

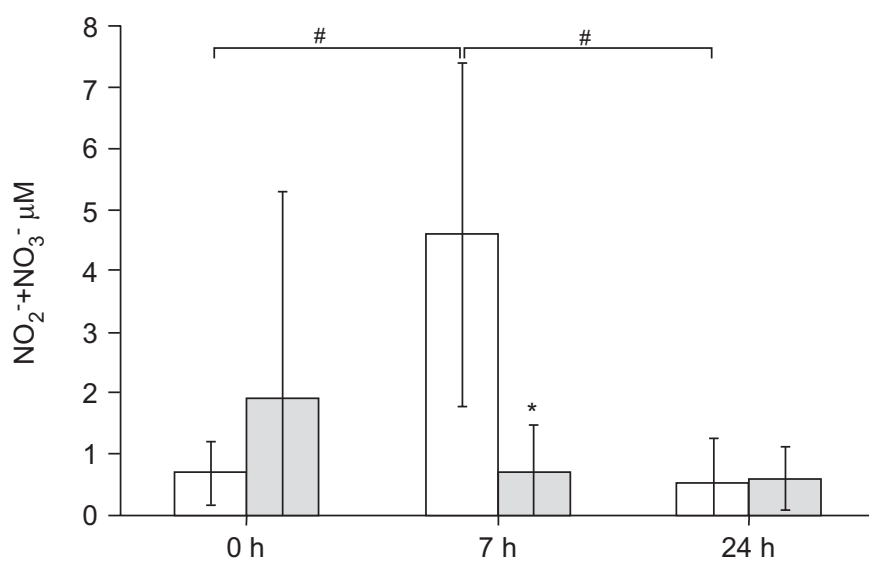

FIGURE 2. Time course of $\mathrm{NO}^{\circ}$ products $\left(\mathrm{NO}_{2}^{-}\right.$and $\left.\mathrm{NO}_{3}{ }^{-}\right)$concentration in bronchoalveolar lavage fluid from pigs subjected to liver devascularisation $(0 \mathrm{~h})$ Pigs in the control group $(\square)$ did not receive antioxidant therapy, while in the desferrioxamine group $(\square)$ they received post-operative i.v. infusion of desferrioxamine for $24 \mathrm{~h} .{ }^{*}: \mathrm{p}<0.05$ between the two groups at $7 \mathrm{~h} ;{ }^{*}: \mathrm{p}<0.05$ between successive time-points in the control group. group. This could be attributed to contamination of BALF by $\mathrm{PLA}_{2}$ and PAF-AcH from plasma, where both enzymes exist in high concentrations, obliterating the differences. Nonetheless, the decreased pulmonary $\mathrm{PLA}_{2}$ activity indicates an indirect protective effect of DFX on surfactant and a possible mechanism for the reduced alveolar collapse.

In contrast to controls, the composition of BALF cells in the DFX group did not change significantly. Although the antioxidant and anti-inflammatory effects of DFX did not result in direct differences in immune cells counts, it could be possible that DFX altered immune cells functions. It has been shown elsewhere that DFX inhibits neutrophil-induced endothelial cell dysfunction and death [26]. In addition, when RITTER et al. [12] administered DFX during lipopolysaccharideinduced lung injury, alveolar macrophage function changed before changes in BALF cell counts could be seen. In that study, the effect of DFX on BALF cell counts became apparent only $48 \mathrm{~h}$ after the initial insult [12]. A similar effect could also be assumed for our model, since the decreased PLA 2 activity could indicate a shift in immune cell function. However, in vitro investigation would be more appropriate to clarify the effect of DFX on immune cells. 


\begin{tabular}{|c|c|c|c|c|}
\hline Parameter & Baseline & $\mathrm{Oh}$ & $7 \mathrm{~h}$ & $24 \mathrm{~h}$ \\
\hline Control group & $90 \pm 8$ & $88 \pm 5$ & $52 \pm 19^{\circ}$ & $50 \pm 15^{\#, \cdots}$ \\
\hline DFX group & $91 \pm 6$ & $93 \pm 4$ & $61 \pm 22$ & $54 \pm 22$ \\
\hline \multicolumn{5}{|c|}{$\begin{array}{l}\text { Alveolar macrophages } \times 10^{3} \\
\text { cells } \mathrm{mL}^{-1}\end{array}$} \\
\hline Control group & $17 \pm 1$ & $299 \pm 160$ & $526 \pm 321$ & $522 \pm 412$ \\
\hline DFX group & $17 \pm 1$ & $920 \pm 180^{\#}$ & $731 \pm 130^{\#}$ & $1004 \pm 587$ \\
\hline \multicolumn{5}{|l|}{ Neutrophils \% } \\
\hline Control group & $7 \pm 4$ & $2 \pm 3$ & $43 \pm 18^{\circ}$ & $42 \pm 16^{\circ}$ \\
\hline DFX group & $6 \pm 3$ & $1 \pm 1$ & $34 \pm 21$ & $34 \pm 20$ \\
\hline \multicolumn{5}{|c|}{ Neutrophils $\times 10^{3}$ cells $\cdot \mathrm{mL}^{-1}$} \\
\hline Control group & $19 \pm 4$ & $448 \pm 322$ & $927 \pm 318^{\# \#}$ & $1014 \pm 705$ \\
\hline DFX group & $18 \pm 5$ & $986 \pm 434$ & $1377 \pm 688$ & $1932 \pm 1173$ \\
\hline
\end{tabular}

Data are presented as mean $\pm \mathrm{SD}$. Ventilation settings were: tidal volume $10 \mathrm{~mL} \cdot \mathrm{kg}^{-1}$, no positive end-expiratory pressure, inspiratory oxygen fraction of 0.60 , respiratory rate adjustment of $10-15$ breaths $\cdot \mathrm{min}^{-1}$ to maintain end-tidal $\mathrm{CO}_{2}$ tension between $35-45 \mathrm{mmHg} .{ }^{\#}: \mathrm{p}<0.05$ and ${ }^{\# \#}: \mathrm{p}<0.01$ compared with baseline values; " : $p<0.05$ and $"$ : $\mathrm{p}<0.01$ compared with $0 \mathrm{~h}$ (immediately after completion of surgery).

In microscopy, two parameters of great importance to lung function were affected by the antioxidant treatment: AEC necrosis and alveolar collapse. AECs contribute to gas exchange and also protect the alveolar spaces against protein and plasma influx [27]. However, the large surface of the alveolar-capillary membrane renders it susceptible to systemic oxidative injury leading to protein and lipid oxidation, cell necrosis and atelectasis due to surfactant depletion [4, 5, 20]. Scavenging of NO products and $\mathrm{H}_{2} \mathrm{O}_{2}$ and inhibition of lipid peroxidation seems to have efficiently inhibited alveolar cell necrosis. Since surfactant production by the AECs is crucial in preventing alveolar space collapse, it could be assumed that prevention of alveolar collapse was, at least partially, due to preservation of the alveolar cells.

\begin{tabular}{llcc} 
TABLE 5 & Histological examination of lung tissue \\
\cline { 2 - 3 } Parameter & \multicolumn{2}{c}{ Group } & p-value \\
\cline { 2 - 3 } & Control & DFX \\
\hline Alveolar collapse & $2.4 \pm 1.1$ & $1.3 \pm 0.6$ & 0.043 \\
Haemorrhage & $1.2 \pm 1.1$ & $0.8 \pm 0.7$ & 0.383 \\
Oedema & $0.8 \pm 0.8$ & $1.2 \pm 0.4$ & 0.270 \\
AEC necrosis & $2.0 \pm 1.2$ & $0.4 \pm 0.5$ & 0.007 \\
Lymphocytes & $2.1 \pm 0.9$ & $1.1 \pm 0.8$ & 0.071 \\
Leukocytes & $1.2 \pm 1.3$ & $0.4 \pm 0.5$ & 0.131 \\
Total lung injury score & $9.7 \pm 4.4$ & $5.2 \pm 2.6$ & 0.038 \\
\hline
\end{tabular}

Data are presented as mean $\pm \mathrm{SD}$, unless otherwise stated. DFX: desferrioxamine; AEC: alveolar epithelial cell.
Causes other than ALF could have contributed to the development of lung injury, such as intraoperative hypovolaemic shock, septic shock and intestinal ischaemia. However, none of these was observed. Theoretically, intracranial hypertension could induce neurogenic pulmonary oedema but this is inconsistent with the protein-rich BALF [28]. Another limitation is the rapidity and severity of ALF, which both represent extreme situations in clinical practice. It is, therefore, possible that the more prolonged clinical process of ALF allows other mechanisms to intervene. It is also notable that, despite the histological alterations, $\mathrm{Pa}_{1} \mathrm{O}_{2}$ remained unaffected. In this respect, it seems more appropriate to refer to this model as a model of minor lung injury. However, during the anhepatic phase of liver transplantation, total body oxygen consumption was shown to decrease by over 35\% [29]. Since our animals remained anhepatic, the $\mathrm{Pa}_{1} \mathrm{O}_{2} / \mathrm{FI}, \mathrm{O}_{2}$ ratio may not be accurate for estimating differences in gas exchange. Nonetheless, experiments on oxygen metabolism and gas exchange in anhepatic animals would be more appropriate to clarify this issue.

Mechanical ventilation could contribute to pulmonary alterations but, as previously described [3], ALF can be considered the major cause of lung injury in this model. Although we chose a relatively high $\mathrm{F}, \mathrm{O}_{2}$ to ensure adequate oxygenation throughout the $24 \mathrm{~h}$; the results showed that this was unnecessary and can be avoided in future experiments. Another limitation is that the respiratory frequency was adjusted according to end-tidal $\mathrm{CO}_{2}$ tension, leading to slight hypocapnia. Although this allowed continuous maintenance of end-tidal $\mathrm{CO}_{2}$ tension between $35-45 \mathrm{mmHg}$, following the $\mathrm{Pa}, \mathrm{CO}_{2}$ values perhaps would help optimise the present model. However, the hypotension observed in controls may have also contributed to hypocapnia. 

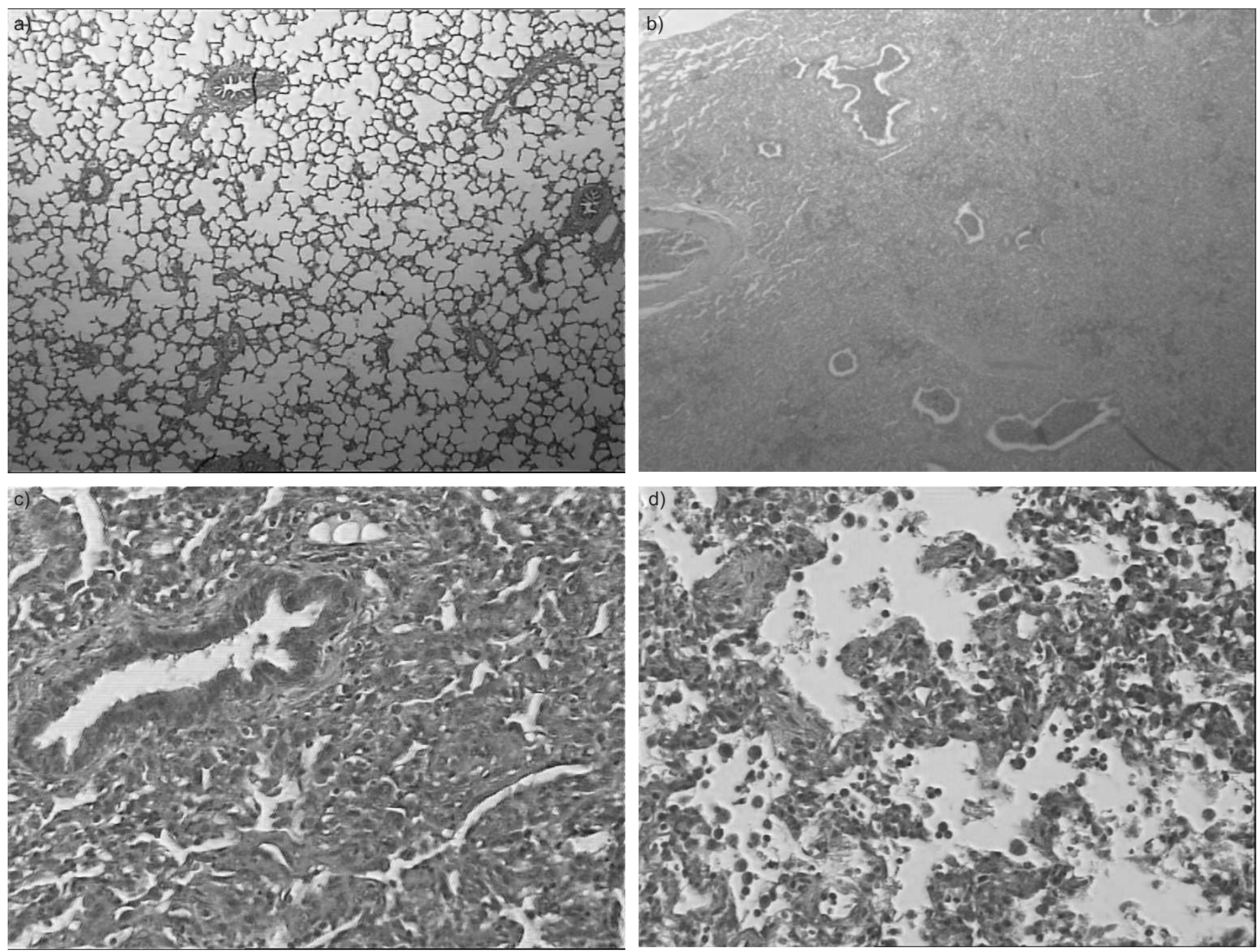

FIGURE 3. Haematoxylin-eosin sections of lungs from a) desferrioxamine and b-d) control groups. a) A normal region of the lung (original magnification $\times 25$ ); b) a region with extensive atelectatic changes (original magnification $\times 25$ ); c) larger magnification of a collapsed region (original magnification $\times 100)$; d) intra-alveolar apoptotic alveolar epithelial cells detached from the alveolar wall (original magnification $\times 100$ ).

Finally, although prolonged administration of DFX was reported to cause ARDS, this was attributed to iron-DFX- $\mathrm{O}_{2}$ interaction [30]. Nonetheless, DFX is a powerful and indiscriminate iron chelator and its use for conditions without iron overload must be viewed cautiously.

\section{Summary}

Infusion of DFX during liver devascularisation seems effective in attenuating systemic and pulmonary oxidative stress. Antioxidant therapy prevented AEC necrosis and alveolocapillary membrane disruption, which seem to be characteristics of the minor lung damage during ALF. In addition, downregulation of $\mathrm{PLA}_{2}$ could limit surfactant hydrolysis, improving atelectasis. Our experimental study is the first to provide a possible treatment of pulmonary injury during ALF. Given the encouraging results and safety of the treatment, clinical studies should investigate its possible benefits in subjects with ALF presenting evidence of lung injury.

\section{ACKNOWLEDGEMENTS}

The authors would like to thank A. Kollintza (Evangelismos Hospital, Athens, Greece) for counting bronchoalveolar lavage fluid cells and E. Galiatsou (University Hospital of Ioannina, Ioannina, Greece) for her expert advice on statistical analysis, as well as G. Kampouroglou, C. Kostopanagiotou, D. Kypriotis and N.A. Papoutsidakis (Aretaieion Hospital, Athens, Greece) for their technical assistance during the experiments.

\section{REFERENCES}

1 Ellis A, Wendon J. Circulatory, respiratory, cerebral and renal derangements in acute liver failure: pathophysiology and management. Semin Liver Dis 1996; 16: 379-388.

2 Baudouin SV, Howdle P, O'Grady JG, et al. Acute lung injury in fulminant hepatic failure following paracetamol poisoning. Thorax 1995; 50: 399-402.

3 Kostopanagiotou G, Routsi C, Smyrniotis V, et al. Alterations in bronchoalveolar lavage fluid during 
ischemia-induced acute hepatic failure in the pig. Hepatology 2003; 37: 1130-1138.

4 Chow CW, Herrera Abreu MT, Suzuki T, et al. Oxidative stress and acute lung injury. Am J Respir Cell Mol Biol 2003; 29: 427-431.

5 Lang JD, McArdle PJ, O'Reilly PJ, et al. Oxidantantioxidant balance in acute lung injury. Chest 2002; 122: 314S-320S.

6 Mansour MA. Protective effects of thymoquinone and desferrioxamine against hepatotoxicity of carbon tetrachloride in mice. Life Sci 2000; 66: 2583-2591.

7 Aller MA, García-Fernández MI, Sánchez-Patán F, et al. Plasma redox status is impaired in the portacaval shunted rat: the risk of the reduced antioxidant ability. Comp Hepatol 2008; 7: 1.

8 Sathyasaikumar KV, Swapna I, Reddy PV, et al. Fulminant hepatic failure in rats induces oxidative stress differentially in cerebral cortex, cerebellum and pons medulla. Neurochem Res 2007; 32: 517-524.

9 Park K, Chung KY, Sung SH, et al. Protective effects of desferrioxamine during canine liver transplantation: significance of peritransplant liver biopsy. Transplant Proc 2003; 35: 117-119.

10 Bartesaghi S, Trujillo M, Denicola A, et al. Reactions of desferrioxamine with peroxynitrite-derived carbonate and nitrogen dioxide radicals. Free Radic Biol Med 2004; 36: 471-483.

11 Ghio AJ, Carter JD, Richards JH, et al. Iron and iron-related proteins in the lower respiratory tract of patients with acute respiratory distress syndrome. Crit Care Med 2003; 31: 395-400.

12 Ritter C, da Cunha AA, Echer IC, et al. Effects of $N$ acetylcysteine plus deferoxamine in lipopolysaccharideinduced acute lung injury in the rat. Crit Care Med 2006; 34 : 471-477.

13 Khanlou H, Souto H, Lippmann M, et al. Resolution of adult respiratory distress syndrome after recovery from fulminant hepatic failure. Am J Med Sci 1999; 317: 134-136.

14 Lowry $\mathrm{OH}$, Rosebrough NJ, Farr AL, et al. Protein measurement with the Folin phenol reagent. J Biol Chem 1951; 193: 265-275.

15 Kitsiouli EI, Nakos G, Lekka ME. Differential determination of phospholipase $\mathrm{A}_{2}$ and PAF-acetylhydrolase in biological fluids using fluorescent substrates. J Lipid Res 1999; 40: 2346-2356.

16 Nakos G, Kitsiouli EI, Tsangaris I, et al. Bronchoalveolar lavage fluid characteristics of early, intermediate and late phases of ARDS. Alterations in leukocytes, proteins, PAF and surfactant components. Intensive Care Med 1998; 24: 296-303.
17 Germann PG, Häfner D. A rat model of acute respiratory distress syndrome (ARDS): Part 1. Time dependency of histological and pathological changes. J Pharmacol Toxicol Methods 1998; 40: 101-107.

18 Turi JL, Yang F, Garrick MD, et al. The iron cycle and oxidative stress in the lung. Free Radic Biol Med 2004; 36: 850-857.

19 Funda A, Guniz M, Sibel E, et al. The effects of intratracheal dexamethasone on acute lung injury in rabbits - experimental study. Middle East J Anesthesiol 2005; 18: 161-171.

20 Zhu S, Ware LB, Geiser T, et al. Increased levels of nitrate and surfactant protein A nitration in the pulmonary edema fluid of patients with acute lung injury. Am J Respir Crit Care Med 2001; 163: 166-172.

21 Mumby S, Block R, Petros AJ, et al. Hydrogen peroxide and catalase are inversely related in adult patients undergoing cardiopulmonary bypass: implications for antioxidant protection. Redox Rep 1999; 4: 49-52.

22 Campillo B, Chabrier PE, Pelle G, et al. Inhibition of nitric oxide synthesis in the forearm arterial bed of patients with advanced cirrhosis. Hepatology 1995; 22: 1423-1429.

23 Von Wichert P, Joseph K, Müller B, et al. Bronchoalveolar lavage. Quantitation of intraalveolar fluid? Am Rev Respir Dis 1993; 147: 148-152.

24 Furue S, Kuwabara K, Mikawa K, et al. Crucial role of group IIA phospholipase $\mathrm{A}_{2}$ in oleic acid-induced acute lung injury in rabbits. Am J Respir Crit Care Med 1999; 160: 1292-1302.

25 Weiland JE, Davis WB, Holter JF, et al. Lung neutrophils in the adult respiratory distress syndrome. Clinical and pathophysiologic significance. Am Rev Respir Dis 1986; 133: 218-225.

26 Chen X, Catravas JD. Neutrophil-mediated endothelial angiotensin-converting enzyme dysfunction: role of oxygen-derived free radicals. Am J Physiol 1993; 265: L243-L249.

27 Holter JF, Weiland JE, Pacht ER, et al. Protein permeability in the adult respiratory distress syndrome. Loss of size selectivity of the alveolar epithelium. J Clin Invest 1986; 78: 1513-1522.

28 Smith WS, Matthay MA. Evidence for a hydrostatic mechanism in human neurogenic pulmonary edema. Chest 1997; 111: 1326-1333.

29 Shangraw RE, Robinson ST. Oxygen metabolism during liver transplantation: the effect of dichloroacetate. Anesth Analg 1997; 85: 746-752.

30 Adamson IY, Sienko A, Tenenbein M. Pulmonary toxicity of deferoxamine in iron-poisoned mice. Toxicol Appl Pharmacol 1993; 120: 13-19. 